\title{
SISTEM PENGELOLAAN SAMPAH PERKOTAAN DI KOTA BIMA PROVINSI NUSA TENGGARA BARAT (SYSTEM OF MUNICIPAL SOLID WASTE MANAGEMENT IN BIMA CITY WEST NUSA TENGGARA PROVINCE)
}

\author{
Wahyudin $^{1 *}$, Siti Syamsiah² dan Sunjoto ${ }^{3}$ \\ ${ }^{1}$ Program Studi Teknik Lingkungan, Sekolah Tinggi Teknik Lingkungan Mataram, \\ Jln. Bung Karno No. 60 Pesongoran, Mataram, Nusa Tenggara Barat 83127 \\ ${ }^{2}$ Departemen Teknik Kimia, Fakultas Teknik, Universitas Gadjah Mada, \\ Jl. Grafika No. 2 Barek, Yogyakarta 55281 \\ ${ }^{3}$ Departemen Teknik Sipil dan Lingkungan, Fakultas Teknik, Universitas Gadjah Mada, \\ Jl. Grafika No. 2 Barek, Yogyakarta 55281
}

*Penulis korespondensi. Tel: 082359478251. Email: wahyudin.mts@ gmail.com.

Diterima: 8 Juni 2017

Disetujui: 28 Agustus 2017

\begin{abstract}
ABSTRAK
Sistem pengelolaan sampah perkotaan di Indonesia pada umumnya masih menerapkan metode konvensional. Lain pihak volume sampah terus mengalami peningkatan seiring dengan meningkatnya jumlah penduduk dan pola hidup masyarakat. Hal itu juga terjadi di wilayah Kota Bima Provinsi Nusa Tenggara Barat, di mana sistem pengelolaan sampah belum berjalan dengan baik. Tujuan penelitian ini adalah mengetahui karakteristik sampah dan sistem pengelolaannya, serta membuat rencana pengembangan sistem pengelolaan sebagai suatu solusi penanganan permasalahan sampah. Penelitian ini menggunakan pendekatan rasional dengan teknik analisis yang digunakan adalah analisis kualitatif dan kuantitatif yaitu berdasarkan standar normatif dan distribusi frekuensi. Hasil dari penelitian tersebut menunjukkan bahwa komponen sistem pengelolaan sampah di Kota Bima masih di bawah standar pengelolaan sampah perkotaan. Hal itu diperoleh dari hasil analisis pendapat masyarakat dan analisis berdasarkan standar normatif. Perencanaan sistem pengelolaan sampah perkotaan di Kota Bima dengan konsep non-konvensional mampu mengurangi timbulan sampah yang dibuang ke TPA sebesar 46,23\% dan memperoleh keuntungan yang dimulai pada tahun ke 13 umur proyek dengan keuntungan total pada hingga akhir periode proyek sebesar Rp. 78.949.779.000.
\end{abstract}

Kata kunci: sampah, perkotaan, pengelolaan, sistem, pengembangan, perencanaan.

\begin{abstract}
Commonly, Municipal Solid Waste (MSW) management in urban life, Indonesia still applies conventional system. Otherwise, solid waste volume gets higher as population and lifestyle, but not supports its management well. It also occurs in Bima City West Nusa Tenggara Province, where the waste management system has not gone well. The purpose of this study is to find out the characteristics of waste and its management system, as well as to make a plan for developing a management system as a solution for handling waste problems. This research applies rational approach with the analysis techniques used are qualitative and quantitative analysis based on normative standards and frequency distribution. The results of this study indicate that the components of the waste management system in the city of Bima are still below the standard of MSW Management. This was obtained from the results of the analysis of public opinion and analysis based on normative standards. The planning of MSW management system in Bima City with nonconventional concept can reduce the amount of waste disposed to the landfill by $46.23 \%$ and earn profits starting on the 13 th year of project age with total profit at the end of the project period of Rp. 78,949,779,000.
\end{abstract}

Keywords: solid waste, municipal, management, system, development, planning.

\section{PENDAHULUAN}

Kecenderungan jumlah penduduk yang semakin meningkat dewasa ini diikuti kegiatan kota yang makin berkembang menimbulkan dampak kecenderungan buangan/limbah yang meningkat dan bervariasi. Menurut Kodoatie (2005), jumlah dan laju penduduk perkotaan yang cenderung meningkat mengakibatkan sistem infrastruktur yang ada menjadi tidak memadai, karena penyediaannya lebih rendah dibandingkan dengan perkembangan 
penduduk. Hal ini dapat menghasilkan kota menjadi tempat yang tidak nyaman.

Penanganan persoalan persampahan menjadi sangat penting untuk setiap daerah, karena berdampak pada citra daerah itu sendiri. Pengelolaan sampah perkotaan yang baik, seperti yang diterapkan di Daerah Istimewa Yogyakarta (DIY) yakni dengan menetapkan suatu kebijakan daerah baik berupa kelembagaan pengelola, perkembangan kualitas lingkungan dan masyarakat, serta pelaksanaan pemantauan dan evaluasi pelaksanaan. Dampaknya adalah meningkatkan kualitas lingkungan, perekonomian, sosial kemasyarakatan, dan budaya lingkungan. (Mulasari dkk., 2014). Untuk pengelolaan sampah perkotaan di Kota Bima masih banyak kendala, yang paling mendasar adalah pola pengelolaan yang masih bersifat konvensional. Kondisi permasalahan diperparah dengan jumlah timbulan sampah yang meningkat drastis yakni pada tahun 2010 yang berjumlah $59.137 \mathrm{~m}^{3}$, dan pada tahun 2011 menjadi $71.175 \mathrm{~m}^{3}$ (Anonim, 2012). Lain pihak ketersediaan TPA Oi Fo'o sebagai sarana pembuangan akhir sampah di Kota Bima seluas $8 \mathrm{Ha}$ dan tersisa $5 \mathrm{Ha}$, dengan sistem open dumping.

Berdasarkan kondisi pengelolaan sampah perkotaan di Kota Bima tersebut, diyakini masih jauh dari standar pengelolaan sampah yang baik. Hal itu menjadi sulit dicapai oleh Kota Bima, karena kesadaran masyarakat yang masih rendah, yakni sebagian besar masyarakat menangani sampah dengan cara dibakar, dibuang di sungai, dan dimbuang sampah di sembarang tempat. (Darmawan, 2014).

Salah satu contoh daerah dengan kesadaran masyarakat yang tinggi adalah di daerah Tasikmalaya. Kebijakan yang diterapkan adalah dengan merubah paradigma masyarakat mengenai sampah secara berkelanjutan. Edukasi kesadaraan dan keterampilan warga untuk pengelolaan sampah dengan penerapan prinsip reduce, reuse, recycle dan replant (4R) penting dalam penyelesaian masalah sampah melalui pengelolaan sampah sejak dari sumbernya. Kebijakan itu memberikan dampak terbentuknya kemandirian dan keswadayaan warga melalui terbentuknya kesadaran, pengetahuan, dan kemampuan yang mendorong partisipasi mengelola lingkungan (Asteria dan
Heruman, 2016). Hal ini dapat menjadi acuan untuk pengelolaan kota lain seperti di Bima ini.

Berdasarkan dari latar belakang masalah tersebut, maka yang menjadi tujuan dari penelitian ini adalah melakukan evaluasi manajemen pengelolan sampah Kota Bima dengan mengetahui karakteristik sampah dan sistem pengelolaannya. Selanjutnya dikembangkan dengan membuat rencana pengembangan sistem pengelolaan sebagai suatu solusi penanganan permasalahan sampah, prioritas pengelolaan, menghitung biaya dan pendapatan dari pengolahan sampah..

\section{METODE PENELITIAN}

\section{Waktu dan Lokasi}

Pelaksanaan penelitian pengelolaan sampah perkotaan di Kota Bima dimulai pada bulan Februari sampai dengan bulan Juli tahun 2013. Pemilihan lokasi penelitian yakni di wilayah Kota Bima, dikarenakan Kota Bima merupakan salah satu pusat pertumbuhan di wilayah provinsi Nusa Tenggara Barat (NTB) khususnya di Pulau Sumbawa, sehingga sistem pengelolaan sampah harus siap menghadapi tingginya aktivitas dan fungsi kota tersebut. Selain itu, buruknya kondisi pengelolaan serta rendahnya kesadaran masyarakat, sehingga diperlukan analisis dan perencanaan pengelolaan sampah Kota Bima.

\section{Prosedur}

Penelitian ini menggunakan pendekatan rasionalistik (deduktif). Proses penelitian dimulai dengan mengidentifikasi permasalahan pengelolaan sampah di Kota Bima. Permasalahan tersebut kemudian dikaji secara teoritis serta mengkaji berdasarkan standar normatif yang telah di tentukan guna menemukan dasar-dasar rasionalitasnya. Berdasarkan kajian teoritis yang ada kemudian dirumuskan pertanyaan penelitian, yang selanjutnya dilakukan pengumpulan data empiris untuk dilakukan proses analisis. Selanjutnya setelah proses analisis dan perencanaan diambil kesimpulan guna menjawab pertanyaan penelitian tersebut. Adapun data dalam penelitian ini berupa data kuantitatif maupun kualitatif.

Jenis data yang diperlukan, mulai dari gambaran umum wilayah Kota Bima, kondisi eksisting pengelolaan sampah yang meliputi 
Tabel 1. Volume timbulan sampah di Kota Bima pada tahun 2007-2011

\begin{tabular}{lrrrrr}
\hline \multirow{2}{*}{ Kecamatan } & \multicolumn{5}{c}{ Timbulan Sampah $\left(\mathrm{m}^{3}\right)$} \\
\cline { 2 - 6 } & \multicolumn{1}{c}{2007} & \multicolumn{1}{c}{2008} & \multicolumn{1}{c}{2009} & \multicolumn{1}{c}{2010} & \multicolumn{1}{c}{2011} \\
\hline Rasanae Barat & 13.840 & 14.117 & 14.822 & 15.118 & 19.710 \\
Rasanae Timur & 9.720 & 9.914 & 10.409 & 10.617 & 12.775 \\
Asakota & 7.226 & 7.371 & 7.734 & 7.518 & 7.665 \\
Mpunda & 12.100 & 12.342 & 12.959 & 13.218 & 11.315 \\
Raba & 9.756 & 9.951 & 10.448 & 10.656 & 19.710 \\
\hline Jumlah & 52.642 & 55.703 & 58.381 & 59.137 & 71.175 \\
\hline Rata-rata Volume $\left(\mathrm{m}^{3} /\right.$ hari $)$ & 146,23 & 147,11 & 154,44 & 156,51 & 159 \\
\hline \multicolumn{1}{c}{ Sumber: Anonim, $2008-2012$} & & & & &
\end{tabular}

data timbulan dan komposisi sampah, serta aspek-aspek dalam pengelolaan sampah perkotaan. Data-data tersebut diperoleh baik dengan cara observasi, kuesioner, wawancara, dan dokumentasi. Kemudian dianalisis dengan cara analisis kualitatif dan kuantitatif. Jenis data yang diperoleh dengan cara penyebaran kuesioner akan dianalisis dengan metode analisis distribusi frekuensi (kuantitatif), sehingga dapat diperoleh persentase pendapat responden. Untuk jenis data yang diperoleh dengan cara observasi dan pengumpulan data sekunder akan dianalisis menggunakan metode atau teknik analisis kualitatif dengan membandingkan dengan standar normatif seperti berdasarkan Standar Nasional Indonesia (SNI), Standar Pelayanan Minimum (SPM), Peraturan atau Undang-undang, pedoman pengelolaan sampah perkotaan, dan teori-teori lain yang relevan dengan pengelolaan sampah.

\section{HASIL DAN PEMBAHASAN}

\section{Gambaran umum sistem pengelolaan sampah \\ Volume timbulan sampah}

Volume timbulan sampah di Kota Bima terlihat mengalami peningkatan pada tiap tahunnya. Pada tahun 2007 volume timbulan sampah sebesar $52.642 \mathrm{~m}^{3}$ dan mengalami peningkatan pada tahun 2011 sebesar 71.175 $\mathrm{m}^{3}$. Jumlah timbulan sampah di Kota Bima ditunjukkan pada Tabel 1.

Peningkatan timbulan sampah di Kota Bima diperkirakan dipengaruhi oleh beberapa faktor yakni pertumbuhan penduduk, pendapatan perkapita, dan aktivitas kota (Wardhana, 2007). Kota Bima sebelumnya merupakan ibu kota kabupaten kemudian berkembang menjadi kota madya. Hal itu terlihat bahwa Kecamatan Rasanae Barat dan Raba merupakan kecamatan yang memiliki
Tabel 2. Komposisi sampah di Kota Bima

\begin{tabular}{lc}
\hline Komposisi sampah & Persentase berat (\%) \\
\hline Organik & 71,40 \\
Anorganik & \\
Plastik & 4,70 \\
Kaca & 1,50 \\
Kertas & 2,30 \\
Karet & 2,20 \\
Logam & 3,70 \\
Kain & 0,83 \\
Lain-lain & 13,37 \\
\hline Jumlah & 100 \\
\hline Sumber: Anonim, 2013
\end{tabular}

Tabel 3. Sarana dan prasana pengelolaan sampah pada tahun 2011

\begin{tabular}{lc}
\hline \multicolumn{1}{c}{ Sarana dan prasarana } & Jumlah unit \\
\hline Dump truck & 16 \\
Arm roll truck & 4 \\
Compactor & 1 \\
Alat berat & 3 \\
Kontainer & 12 \\
Motor tiga roda & 32 \\
TPA & 1 \\
Transfer depo & 1 \\
Gerobak & 40 \\
\hline Sumber: Anonim, 2013
\end{tabular}

timbulan sampah terbanyak. Salah satu faktornya adalah terkait fungsi wilayah pada masing-masing kecamatan, di mana Kecamatan Raba merupakan pusat pemerintahan dan Rasanae Barat merupakan pusat perdagangan dan jasa.

\section{Komposisi sampah}

Komposisi sampah di Kota Bima di dominasi oleh sampah organik yaitu sebanyak $71,40 \%$, sedangkan sisanya adalah sampah anorganik dan sampah lain-lain. Komposisi sampah di Kota Bima secara rinci ditunjukkan pada Tabel 2.

\section{Kondisi Sarana dan prasarana}

Dinas kebersihan, Pertamanan dan Pemakaman (DKPP) Kota Bima, dalam bidang pelaksananya memiliki kegiatan utama operasional di lapangan, tentu saja sarana dan 
Tabel 4. Proyeksi timbulan sampah berdasarkan perkiraan jumlah penduduk tahun 2011-2032

\begin{tabular}{crcc}
\hline Tahun & $\begin{array}{c}\text { Jumlah } \\
\text { Penduduk* }\end{array}$ & $\begin{array}{c}\text { Volume Timbulan Sampah } \\
\left(\mathbf{m}^{\mathbf{3} / \mathbf{h r}}\right)^{* *}\end{array}$ & $\begin{array}{c}\text { Berat Timbulan Sampah } \\
\text { (Ton/hr)*** }\end{array}$ \\
\hline 2011 & 144,018 & 288.04 & 43.21 \\
2012 & 151,219 & 308.53 & 46.36 \\
2017 & 192,998 & 435.07 & 65.91 \\
2022 & 246,320 & 613.52 & 93.72 \\
2027 & 314,373 & 865.14 & 133.25 \\
2032 & 401,229 & 1219.98 & 189.46 \\
\hline
\end{tabular}

Keterangan:
$* \quad$ : Proyeksi dengan metode geometri
** : Proyeksi timbulan sampah dengan timbulan dasar $2 \mathrm{l} / \mathrm{o} / \mathrm{h}$ (Anonim, 2003)
***: Proyeksi berat sampah dengan berat dasar $0,3 \mathrm{~kg} / \mathrm{o} / \mathrm{h}$ (Anonim, 2003)

Tabel 5. Perkiraan jumlah kendaraan pengangkut sampah dan tenaga operasional di Kota Bima tahun 2011-2032

\begin{tabular}{lrrrrrr}
\hline \multirow{1}{*}{ Uraian } & \multicolumn{7}{c}{ Kota Bima } \\
\cline { 2 - 7 } & $\mathbf{2 0 1 1}$ & $\mathbf{2 0 1 2}$ & $\mathbf{2 0 1 7}$ & $\mathbf{2 0 2 2}$ & $\mathbf{2 0 2 7}$ & $\mathbf{2 0 3 2}$ \\
\hline Dump truck & 16 & 16 & 16 & 22 & 33 & 46 \\
Arm roll truck & 4 & 9 & 12 & 16 & 24 & 34 \\
Kontainer & 12 & 26 & 36 & 49 & 72 & 102 \\
Motor roda tiga & 32 & 67 & 94 & 127 & 187 & 198 \\
Gerobak & 40 & 54 & 76 & 68 & 101 & 142 \\
Tenaga kerja & 216 & 267 & 355 & 442 & 655 & 791 \\
\hline Sumber: Hasil analisis, 2013 & & & & & &
\end{tabular}

prasarana adalah hal penting dalam menunjang kegiatan tersebut. Adapun sarana-prasarana yang dimiliki DKPP Kota Bima dalam pengelolaan sampah ditunjukkan pada Tabel 3.

\section{Analisis sistem pengelolaan sampah Proyeksi Timbulan Sampah}

Timbulan sampah perkotaan di Kota Bima diperkirakan berdasarkan jumlah dan persentase pertumbuhan penduduk serta pertumbuhan kota. Pertumbuhan kota dilihat dari perkembangan sektor pertanian, industri dan pertumbuhan PDRB. Total proyeksi sampah perlu memperkirakan pengurangan sampah dari hasil pemilahan dan pemanfaatan sampah. Proyeksi kuantitas sampah di Kota Bima ditunjukkan pada Tabel 4.

Hasil proyeksi menunjukkan terjadinya peningkatan timbulan sampah tiap tahunnya, hal itu berbanding lurus dengan pertumbuhan penduduk, di mana pertumbuhan penduduk Kota Bima sebesar 5,52\%. Hal yang sama diungkapkan oleh Wardhana (2007) bahwa pertumbuhan timbulan sampah diasumsikan sebanding dengan pertumbuhan jumlah penduduk dan tingkat pertumbuhan sosial ekonomi/ tingkat konsumsi masyarakatnya yang direpresentatifkan dengan pertumbuhan PDRB.

\section{Proyeksi Kebutuhan Sarana dan Prasarana}

Proyeksi kebutuhan sarana dan prasarana persampahan berdasarkan jumlah sampah yang dihasilkan pada tahun yang akan datang dapat dilihat pada Tabel 5.

Peningkatan kebutuhan sarana pengangkutan sampah dipengaruhi oleh jumlah timbulan sampah dan target pelayanan. Menurut Raharjo, dkk. (2016) peningkatan kebutuhan sarana pengangkut sampah, ditentukan oleh pola pengelolaan dan tahapan aspek teknis digunakan. Oleh karena itu, jumlah kebutuhan saran pengangkut sampah di atas dapat berkurang dari perkiraan, apabila pengolahan sampah sejak dari sumbernya dioptimalkan.

\section{Sistem Pengelolaan Sampah Subsistem kelembagaan}

Menurut Enri (2010), subsistem kelembagaan merupakan suatu kegiatan yang multi disiplin yang bertumpu pada prinsip teknik dan manajemen yang menyangkut aspek-aspek ekonomi, sosial, budaya, dan kondisi fisik wilayah kota, dan memperhatikan pihak yang dilayani yaitu masyarakat kota.

Berdasarkan Perda Kota Bima No. 3 Tahun 2008 tentang pembentukan susunan, kedudukan tupoksi dinas-dinas daerah Kota Bima. Tugas Dinas Kebersihan, Pertamanan 
dan Pemakaman (DKPP) Kota Bima adalah melaksanakan tugas pemerintahan dan pembangunan dan dekonsentrasi. Dengan demikian, pembentukan DKPP sudah memiliki kekuatan hukum secara jelas dalam melaksanakan tugasnya sebagai instansi pengelolaan sampah di Kota Bima.

Secara struktur organisasi, pengelolaan sampah masih ditangani secara terpusat oleh DKPP, di mana DKPP menangani secara langsung pengelolaan di masing-masing kecamatan ataupun kelurahan. Dengan kondisi seperti itu, sehingga pengelolaan di lingkup kecamatan ataupun kelurahan yang jauh dari pusat kota belum optimal seperti di Kelurahan Kolo dan Kelurahan Lampe yang secara administrasi terletak jauh dari pusat kota. Namun secara umum kinerja instansi pengelola sampah di Kota Bima masuk dalam kategori bagus. Hal itu ditunjukkan dengan pendapat responden yang menyatakan bagus adalah sebesar $61 \%$, sedangkan yang menyatakan tidak bagus adalah hanya $31 \%$.

\section{Subsistem teknik operasional}

Secara umum kondisi maupun kinerja dari aspek teknik operasional pengelolaan sampah Kota Bima tidak bagus, hal ini dapat dilihat dari hasil analisis distribusi frekuensi di mana responden menyatakan tidak bagus yaitu sebesar sebesar 48\%, sedangkan yang menyatakan tidak bagus adalah sejumlah $52 \%$. Pendapat responden tersebut dinilai sangat wajar dengan melihat kondisi operasional pengelolaan sampah di Kota Bima. Rendahnya kesadaran masyarakat menjadi salah satu faktor utama penyebab terhambatnya pelaksanaan pengelolaan sampah di Kota Bima (Darmawan, 2014).

Puspitawati dan Rahdriawan (2012), menyatakan bahwa karakter sosial dan budaya memiliki pengaruh yang lebih besar dalam kegiatan tersebut dibandingkan dengan karakter sosial ekonomi. Partisipasi yang terjadi bersifat bottom-up, dimulai dengan identifikasi masalah dan kebutuhan oleh masyarakat hingga merasakan kemanfaatannya secara bersama. Proses ini dimulai dengan pemberdayaan masyarakat melalui pembangunan kapasitas. Terciptanya budaya hidup bersih, sangat membantu pemerintah dalam mewujudkan lingkungan yang bersih dan indah dengan terlaksananya setiap tahapan operasional pengelolaan sampah.

\section{a. Daerah dan tingkat pelayanan}

Daerah pelayanan persampahan di Kota Bima berdasarkan data sekunder adalah sebanyak 25 kelurahan yang sudah terlayani dari total 38 kelurahan. Dengan demikian, pelayanan persampahan belum secara merata di seluruh wilayah Kota Bima. Menurut Enri (2010), di mana pihak pengelola sampah bertanggung jawab untuk memberikan pelayanan kepada semua wilayah layanannya, paling tidak sampah didaerah tersebut diangkut menuju pengolahan atau pemrosesan akhir. Daerah yang tidak dilayani diharapkan menangani sampahnya secara mandiri baik secara individu, maupun secara komunal.

Penilaian tingkat pelayanan persampahan adalah perbandingan antara jumlah sampah yang terangkut dan total timbulan sampah yang ada di Kota Bima. Berdasarkan data persentase pelayanan masih rendah yaitu $53,16 \%$ yang terlayani, sedangkan yang belum terlayani adalah sebanyak 46,84\%, sedangkan standar pelayanan persampahan pada suatu daerah sekitar 80-100\% (Anonim, 1998).

\section{b. Penyapuan jalan}

Kegiatan penyapuan jalan di Kota Bima masih terfokus pada jalan-jalan utama yang berada di pusat pemerintahan dan di wilayah komersial dengan panjang ruas penyapuan 49,5 $\mathrm{km}$. Penyapuan jalan dilakukan satu kali dalam sehari dan dilakukan tiap pagi hari sekitar jam 00.00 - 07.00 WITA.

Penyapuan jalan di Kota Bima belum optimal karena hanya dilakukan 1 (satu) kali per hari. Menurut standar dalam Pedoman Pengelolaan Sampah Perkotaan bagi Pelaksana (Anonim, 2003), penyapuan jalan harus dilakukan sebanyak dua sampai tiga kali sehari. Oleh karena itu, kedepannya kegiatan penyapuan jalan harus ditingkatkan dan memperluas wilayah penyapuan.

\section{c. Pewadahan}

Pola pewadahan yang baik dan perlu diterapkan adalah dengan melakukan pewadahan sesuai jenis sampah yaitu sampah organik dan anorganik, sehingga dibutuhkan minimal 2 (dua) buah tempat pewadahan. Lokasi penempatan juga harus diperhatikan guna mempermudah petugas dalam melakukan pengumpulan, dianjurkan dalam SNI 19-2454- 
2002 adalah agar menempatkan di depan halaman rumah. Selain pola dan lokasi pewadahan, jenis bahan pewadahan juga diatur dalam SNI 19-2454-2002, di mana bahan pewadah harus memenuhi kriteria tidak mudah rusak dan kedap air, ekonomis, dan mudah dikosongkan. Apabila memperhatikan standar tersebut diatas, maka perbaikan pewadahan di wilayah kota Bima sangat diperlukan, terutama pengadaan peawadah pemilahan sampah.

\section{d. Pengumpulan}

Pola pengumpulan dan frekuensi pengumpulan akan tergantung pada jumlah sampah, waktu, status sosial ekonomi daerah yang dilayani, dan tanggung jawab pemerintah (Tchobanoglous, 2002). Proses pengumpulan sampah di wilayah Kota Bima dilakukan dengan menggunakan kendaraan roda tiga yang sudah tersedia pada masing-masing kelurahan, namun belum seluruh kelurahan memperoleh kendaraan tersebut. Pola pengumpulan adalah dengan menerapkan sistem door to door yaitu mengambil langsung ke rumah-rumah masyarakat. Frekuensi pengumpulan yang dilakukan oleh petugas kebersihan sebanyak tiga kali dalam seminggu. Pola pengumpulan yang diterapkan di Kota Bima sudah bagus, namun yang perlu peningkatan baik pola pengangkutan berdasarkan jenis sampah maupun frekuensi pengangkutannya.

\section{e. Pemindahan}

Kegiatan pemindahan pada saat ini hanya terdapat di tempat transfer depo, yang berlokasi di wilayah DKPP. Proses pemindahan yang dilakukan adalah sampah yang di kumpulkan dengan kendaraan roda tiga di pindahkan ke truk pengangkut sampah untuk di buang ke TPA. Kondisi fasilitas pemindahan sampah perlu didesain ulang, di mana kondisi pemindahan sekarang ketinggian antara motor roda tiga sebagai sumber sampah sejajar dengan penempatan dump truk, sehingga proses pemindahannya cenderung mengalami kesulitan. Usulan untuk desain fasilitas pemindahan yang baru, seperti lokasi motor roda 3 sebagai sumber sampah yang akan dipindahkan ke dump truk harus lebih tinggi dari posisi penempatan dump truknya.

\section{f. Pengangkutan}

Proses pengangkutan sampah di Kota Bima menggunakan 2 jenis kendaraan, yang masing-masing menerapkan jenis pengangkutan yang berbeda. Pertama, proses pengangkutan di lokasi transfer depo menggunakan kendaraan dump truck sebanyak 14 unit dan 2 unit dump truck lainnya dioperasikan ditempat lain, seperti melayani kegiatan gotong-royong kebersihan. Lokasi transfer depo di Kota Bima terdapat hanya 1 unit, sehingga kendaraan dump truck memiliki jadwal antri untuk pengangkutan. Kedua, pola pengangkutan kontainer adalah menggunakan sistem pengangkutan kontainer cara satu, yaitu kendaraan berangkat ke lokasi kontainer isi pertama, lalu diangkut ke TPA. Setelah kembali dari TPA, kendaraan langsung menuju kontainer isi berikutnya, dan pola pengangkutannya sama pada kontainer pertama.

\section{g. Pengolahan dan pemanfaatan}

Berdasarkan hasil wawancara dan pengamatan di lapangan, kegiatan pengolahan sampah sama sekali belum diterapkan baik oleh pemerintah maupun masyarakat Kota Bima. Dengan kondisi seperti itu, seperti yang dimandatkan dalam undang-undang pengolahan sampah bahwa tidak ada lagi pembuangan akhir sampah, tapi pengolahan akhir sampah. Pengolahan sampah layaknya dilakukan mulai dari sumber sampah hingga ke TPA sampah-sampah tersebut harus diolah dan dimanfaatkan (Cecep, 2012).

\section{h. Pembuangan/pemrosesan akhir}

TPA di Kota Bima mempunyai luas area sekitar 8 Ha dan sudah tertimbun sekitar 5 Ha. TPA yang terdapat di Kota Bima menerapkan sistem open dumping, sedangkan menurut undang-undang No. 18 Tahun 2008 tentang persampahan, di mana pada pasal 44 bahwa pemerintah daerah harus menutup TPA dengan sistem open dumping.

Menurut Sahil, dkk. (2016) dalam penelitiannya mengemukakan bahwa metode pengumpulan sampah dengan metode secara langsung dan langsung ditampung di TPA dibiarkan secara open dumping tanpa ada pengolahan lanjutan, metode ini akan berdampak buruk karena dengan peningkatan jumlah penduduk pertahunnya juga meningkatnya jumlah timbulan sampah, sehingga lahan TPA yang mempunyai luas terbatas tidak dapat lagi menampung sampah.

Berdasarkan kondisi TPA di Kota Bima dan kebijakan yang mengatur tentang TPA, 
maka Pemerintah Kota Bima harus menutup TPA lama, dan membangun TPA sesuai dengan peraturan yang berlaku. Proyeksi kebutuhan lahan untuk 20 tahun yang akan datang perlu dilakukan untuk kebutuhan perencanaan dan desain TPA. Proyeksi kebutuhan lahan TPA berdasarkan petunjuk teknis nomor CT/S/Re-CT/004/98, maka kebutuhan lahan TPA untuk 20 tahun yang akan datang yaitu seluas 9,22 Ha.

\section{Subsistem pembiayaan}

Anggaran pengelolaan sampah berdasarkan SKPD tahun 2011 adalah Rp. 11.207.276.900 dan mengalami peningkatan pada tahun 2012 dengan jumlah Rp. 12.258.489.900. Posisi anggaran pengelolaan sampah pada tahun 2011 sebesar 2,55\% dari total APBD Kota Bima tahun 2011, di mana angka tersebut sangat kecil bila melihat standar dalam Pedoman Pengelolaan Sampah Perkotaan bagi Pelaksana (Anonim, 2003) biaya pengelolaan sampah perkotaan yaitu sebesar $10 \%$ dari total APBD.

\section{Subsistem hukum dan peraturan}

Regulasi yang mengatur pengelolaan sampah di Kota Bima belum dibuat dan ditetapkan oleh pemerintah Kota Bima. Sampai pada saat ini, perda yang ada hanya untuk mengatur retribusi sampah, sedangkan peraturan yang mengatur manajemen pengelolaan sampah dan sanksi-sanksi terhadap pelanggaran dalam pengelolaan sampah belum ditetapkan. Dengan demikian, untuk memaksimalkan kinerja pengelolaan sampah di Kota Bima, maka diperlukan suatu peraturan yang mengatur sepenuhnya tentang pengelolaan sampah.

Menurut Chalik dkk. (2011), bahwa sampah selama ini masih dianggap masalah yang trivial dan belum menjadi sentra kebijakan pemerintah yang serius. Padahal tanpa penanganan sampah yang baik kehidupan sosial ekonomi masyarakat perkotaan akan merasakan dampak negatif yang cukup besar seperti kesehatan dan lingkungan serta konflik spasial menyangkut konflik atas lahan dan wilayah lainnya. Oleh karena itu sudah saatnya kebijakan sampah ini ditangani dengan serius.

\section{Subsistem peran serta masyarakat}

Tingkat partisipasi masyarakat pada saat ini masih sangat minim, di mana hanya sebagian masyarakat yang berpartisipasi dalam membayar retribusi kebersihan dan kesadaran dalam pemanfaatan/pengolahan sampah belum ada. Salah satu potensi yang ada pada masyarakat Kota Bima adalah adanya faktor kebersamaan dan kesadaran gotong-royong yang kuat. Potensi ini dapat dimanfaatkan dalam pengolahan sampah baik skala rumah tangga maupun skala kota.

Partisipasi sebagai salahsatu faktor yang mempengaruhi dalam keberhasilan pengelolaa persampahan, oleh karena itu diperlukan langkah-langkah pemecahan masalah, seperti meningkatkan sosialisasi, melakukan pendekatan-pendekatan pada tokoh masyarakat, meningkatkan kerjasama dengan seluruh stakeholders (Rizal, 2011).

\section{Rencana pengembangan sistem pengelolaan sampah}

\section{Konsep penanganan dan sasaran pengembangan}

Konsep penanganan sampah di Kota Bima adalah dengan menerapkan metode nonkonvensional, yaitu pengelolaan tidak hanya melalui proses pengumpulan, pengangkutan dan pembuangan, tetapi terdapat penanganan lebih lanjut yaitu pemilahan dan pengolahan sampah. Konsep penanganan sampah di Kota Bima dapat dilihat pada Gambar 1.

\section{Pengembangan pengumpulan dan pengangkutan}

Rencana pola pengumpulan dan pengangkutan sampah di Kota Bima, tidak menerapkan pola yang baru, karena pola yang berjalan sekarang sudah bagus. Namun, penambahan sarana dan prasarana serta efektif dalam pengangkutan perlu ditingkatkan. Pola pengumpulan dan pengangkutan dapat dilihat pada Gambar 2.

Berdasarkan pembahasan diatas, sistem pengumpulan dan pengangkutan sampah berikut diusulkan sebagai tahap awal, namun sistem ini perlu direvisi sesuai dengan perubahan kondisi sosial dan fisik. Rencana penempatan dan pemanfaatan sarana persampahan dapat dilihat pada Tabel 6 . 


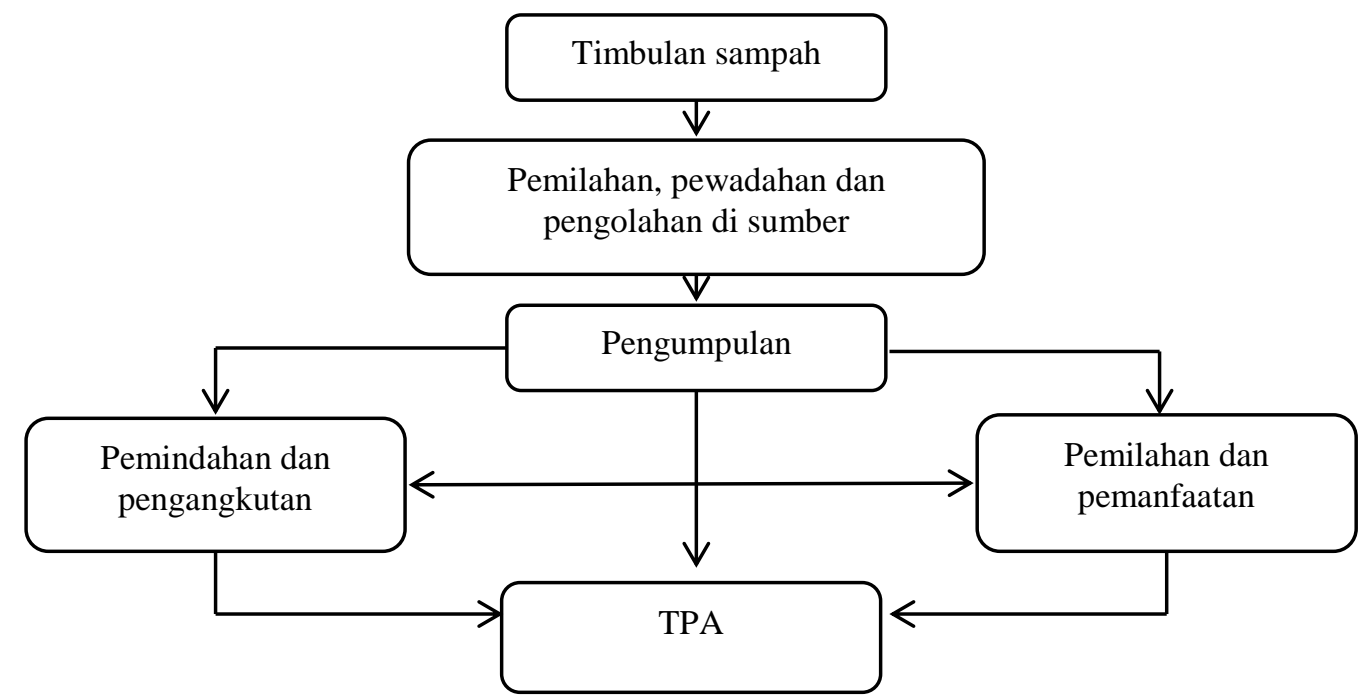

Gambar 1. Pola penanganan sampah di Kota Bima

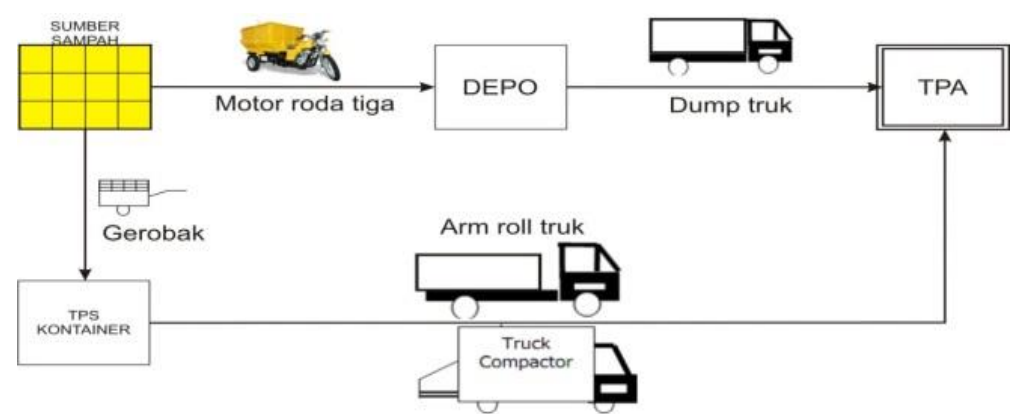

Gambar 2. Rencana pola pengumpulan dan pengangkutan sampah di Kota Bima

Tabel 6. Rencana penempatan sarana persampahan berdasarkan daerah pelayanan

\begin{tabular}{lll}
\hline \multicolumn{1}{c}{ Daerah Sasaran } & \multicolumn{1}{c}{ Sistem } & $\begin{array}{c}\text { Frekuensi } \\
\text { Pengumpulan }\end{array}$ \\
\hline $\begin{array}{l}\text { Untuk daerah dengan kepadatan } \\
\text { penduduk sedang atau tinggi tetapi tanpa } \\
\text { jalan yang cukup lebar untuk kendaraan } \\
\text { pengangkut sampah }\end{array}$ & $\begin{array}{l}\text { Pengenalan sistem pengumpulan primer dan } \\
\text { sistem kontainer angkut (dimana pengumpulan } \\
\text { sekunder dilakukan oleh petugas atau } \\
\text { kendaraan kompaktor (pemadat sampah) }\end{array}$ & $\begin{array}{l}\text { Setiap hari dengan } \\
\text { jumlah ritasi sebanyak } \\
2 \text { rit/hari }\end{array}$ \\
& $\begin{array}{l}\text { Pengumpulan dari rumah ke rumah dengan } \\
\text { gerobak dan motor roda tiga. }\end{array}$ & Setiap hari dengan \\
\hline $\begin{array}{l}\text { Untuk daerah dengan jalan yang cukup } \\
\text { lebar (kawasan komersial dan bisnis, } \\
\text { berpopulasi padat) }\end{array}$ & Sistem kontainer angkut & jumlah ritasi sebanyak \\
\hline $\begin{array}{l}\text { Untuk daerah dengan kepadatan } \\
\text { penduduk sedang atau rendah yang } \\
\text { memiliki jalan yang cukup lebar }\end{array}$ & Pengumpulan di pinggir jalan oleh petugas \\
\hline $\begin{array}{l}\text { Untuk kawasan komersial, bisnis skala } \\
\text { kecil atau kalangan atas }\end{array}$ & $\begin{array}{l}\text { Pengumpulan sampah dari rumah ke rumah oleh } \\
\text { petugas }\end{array}$ & $\begin{array}{l}\text { Setiap hari sebanyak } \\
\text { S rit/hari }\end{array}$ \\
\hline $\begin{array}{l}\text { Untuk pengangkutan di lokasi transfer } \\
\text { depo }\end{array}$ & $\begin{array}{l}\text { Sistem pengumpulan dengan dump truck. } \\
\text { Dump truck memiliki jadwal antri (sift) }\end{array}$ & 3 rit/hari \\
\hline
\end{tabular}

\section{Pengembangan pengolahan sampah}

Berdasarkan hasil perkiraan timbulan sampah yang dibuang ke TPA dan yang dimanfaatkan. Diketahui jumlah sampah yang ditargetkan akan masuk ke TPA pada tahun 2032 sebanyak $655,96 \mathrm{~m}^{3} /$ hari dari total proyeksi timbulan sampah sebesar 564,02 $\mathrm{m}^{3} /$ hari. Pengembangan pengolahan sampah ini akan mampu menangani permasalahan saat ini, di mana $100 \%$ volume sampah di Kota Bima semuanya dibuang ke TPA karena belum ada pengolahan sampah. Penerapan konsep pengo- 


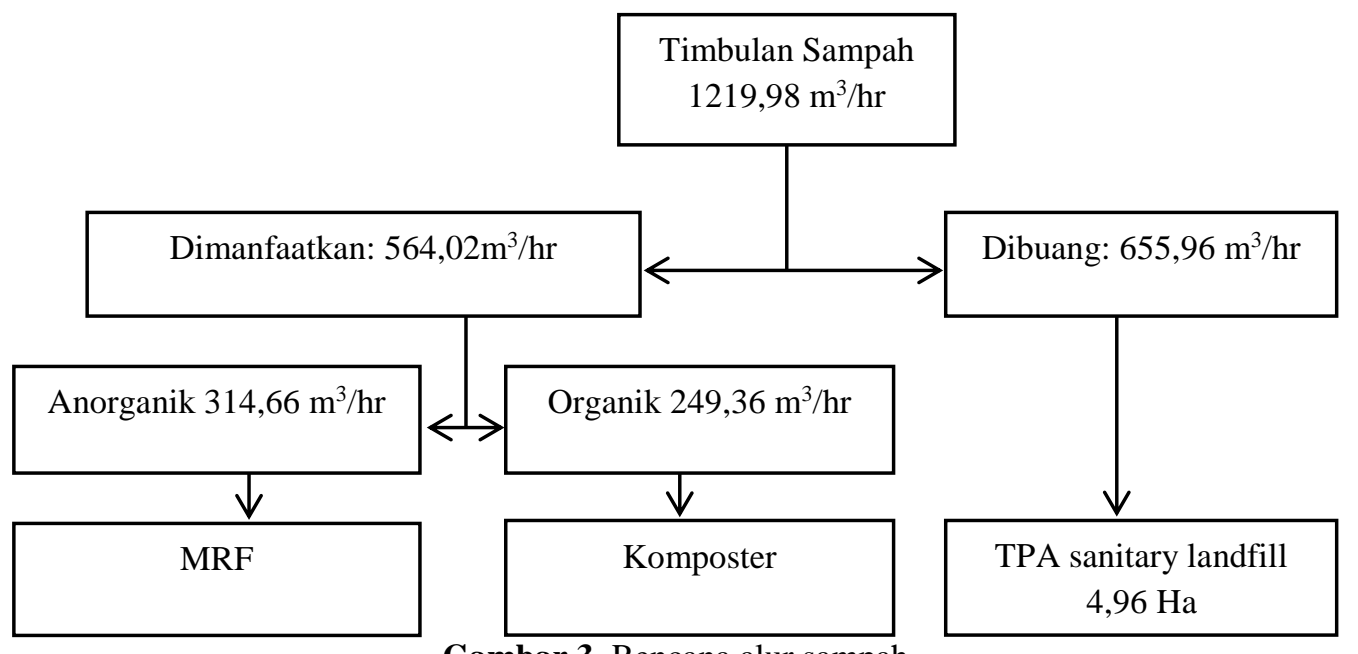

Gambar 3. Rencana alur sampah

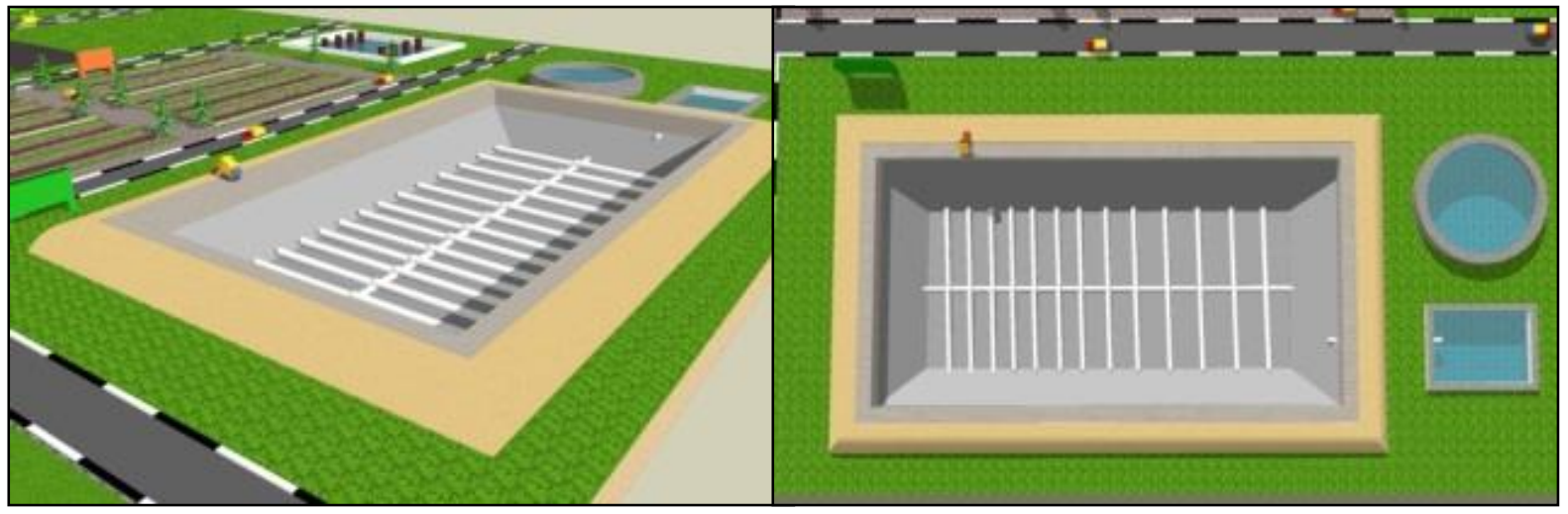

Gambar 4. Rencana konseptual desain TPA sanitary landfill

lahan sampah ini direncanakan akan mampu mengurangi pembuangan sampah ke TPA adalah sebesar 47,45\%. Aliran pengelolaan dan pengolahan sampah di Kota Bima pada tahun 2032 dapat dilihat pada Gambar 3.

Rencana pengolahan sampah diterapkan dalam pengelolaan sampah di Kota Bima terdapat beberapa alternatif. Alternatif pengolahan sampah yang dapat dikembangkan untuk jangka panjang. Pertama, pengolahan sampah skala rumah tangga yang meliputi penggunaan barang atau kemasan yang dapat didaur ulang dan mudah terurai dengan proses alam, membatasi penggunaan kantong plastik, dan menghindari penggunaan barang dan/atau kemasan sekali pakai. Kedua, pengolahan sampah berbasis komunitas (skala kawasan) yaitu model pengolahan sampah ini akan dilakasanakan pada klaster-klaster tertentu. Klaster ini dapat dibentuk di TPA yang meliputi pengolahan sampah di tempat pemrosesan akhir sampah dengan membangun unit pemilahan sampah dan unit pengomposan, sedangkan TPA menerapkan metode sanitary landfill.

\section{Pengembangan tempat pemrosesan akhir}

Peningkatan metode pengoperasian TPA harus dipertimbangkan untuk TPA baru. Metode TPA saniter berikut perlu diterapkan, meliputi perataan dan pemadatan dengan metode dorong, penimbunan dengan tanah harus dilakukan setiap hari untuk mencegah bau yang tidak sedap ataupun penyebaran bakteri, dan pemantauan secara berkala harus dilakukan pada sumur-sumur milik warga di sekitar lokasi TPA.

Berdasarkan pertimbangan tersebut, peningkatan sistem operasi TPA ke sanitary landfill perlu ditetapkan dan direalisasikan. Konseptual desain TPA sanitary landfill dapat dilihat pada Gambar 4.

Terdapat beberapa lahan yang dapat dimanfaatkan untuk pembangunan TPA. Dalam hal ini, pertimbangan melalui pengenalan prosedur-prosedur mitigasi berikut untuk lingkungan sekitar, meliputi penyiapan zona 


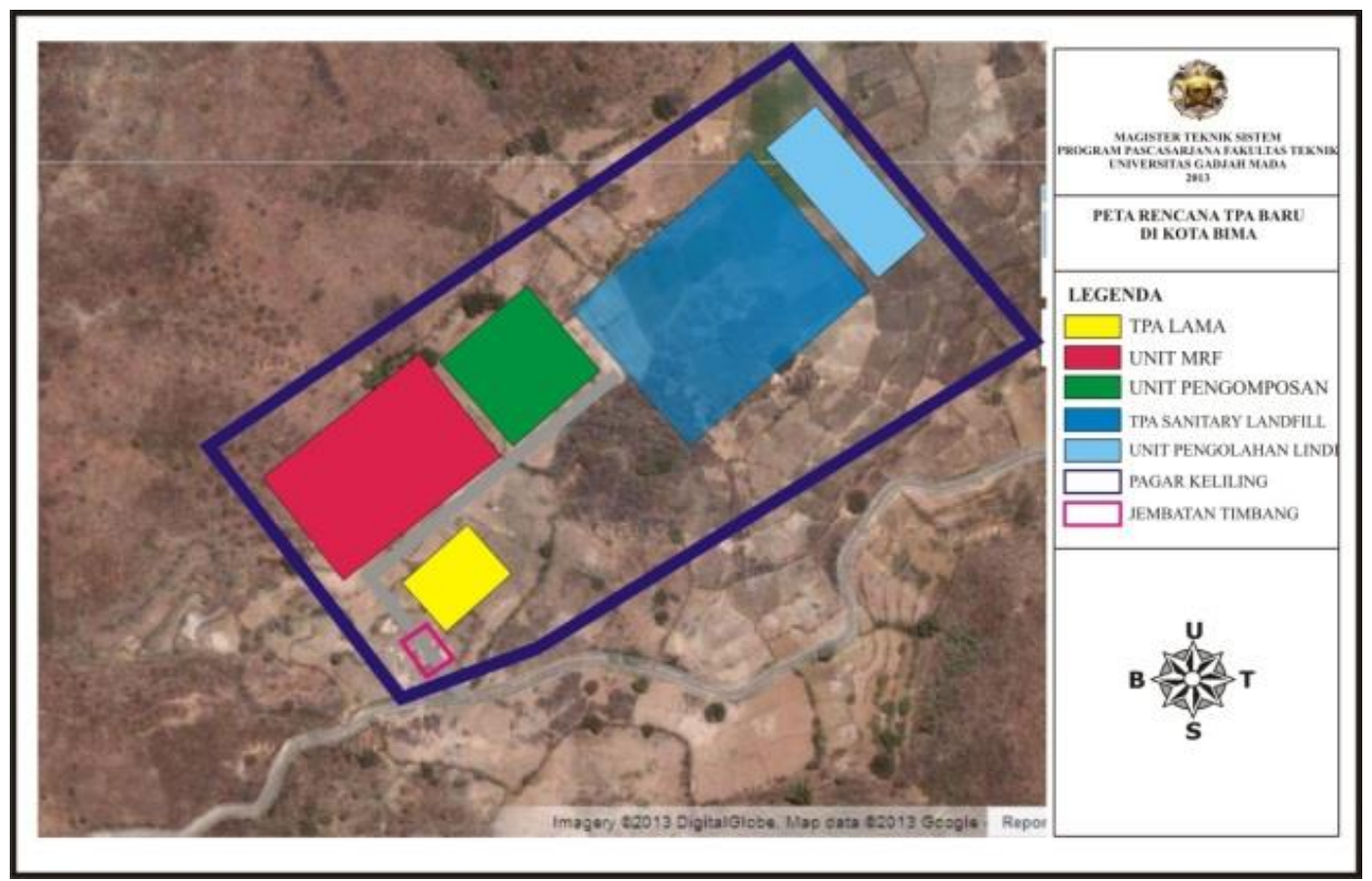

Gambar 5. Rencana Denah TPA baru

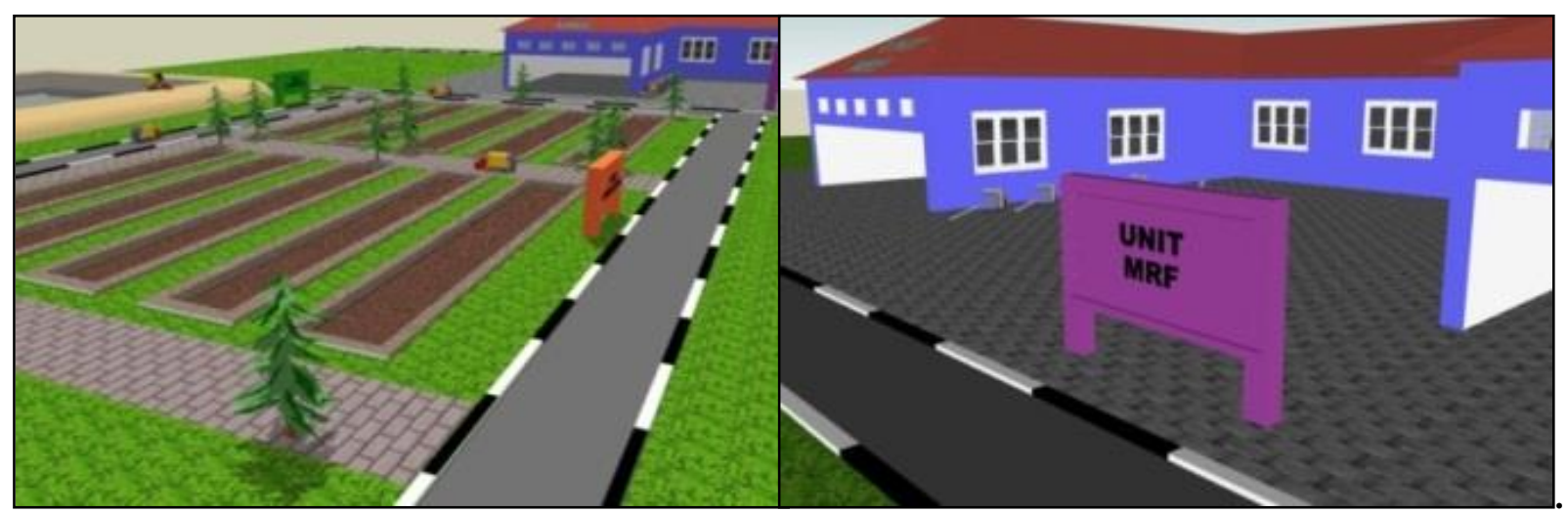

Gambar 6. Konseptual desain unit pengolahan sampah di TPA baru

penyanggah (buffer zone) untuk mengurangi efek bau atau bakteri, perlindungan terhadap kualitas air tanah atau air permukaan dengan mempersiapkan pelapis atau tanggul, melakukan penimbunan dengan tanah setiap hari, dan pengenalan langkah pengoperasian TPA sehat lainnya.

Berdasarkan pertimbangan pada rencana TPA, maka pembangunan TPA baru berlokasi dekat dengan TPA yang lama. Berdasarkan hasil perhitungan proyeksi kebutuhan lahan hingga tahun 2032, diketahui jumlah lahan TPA yang dibutuhkan adalah seluas 9,22 Ha. Secara rinci perencanaan pengembangan TPA dapat dilihat pada Gambar 5.

Unit pengolahan sampah di TPA perlu dipertimbangkan menimbang jumlah timbulan sampah semakin meningkat tiap tahunnya serta kesediaan lahan TPA yang terbatas. Perencanaan fasilitas pengolahan sampah berupa Material Recovery Facility (MRF) yang difungsikan sebagai unit pengolahan sampah di lokasi TPA Kota Bima. Unit pengolahan sampah di lokasi TPA baru, seperti unit pengomposan dan unit MRF dapat dilihat pada Gambar 6.

\section{Pengembangan subsistem kelembagaan}

Penataan organisasi pelaksanaan dilakukan dengan melakukan restrukturisasi tugas pokok dan fungsi yang lebih jelas dan tegas dalam bentuk PERDA. Pendelegasian kewenangan pengelolaan kebersihan dari Dinas Kebersihan dan kecamatan dan kelurahan harus disertai dengan pelimpahan sumber daya yang mencukupi. Pengelolaan sampah antar lembaga harus ada kesatuan, komando dengan membuat struktur organisasi yang eksplisit untuk memperjelas alur komando penanganan permasalahan sampah. 


\section{Pengembangan subsistem hukum dan peraturan}

Rencana sistem pengelolaan persampahan Kota Bima dalam subsistem peraturan dan regulasi, meliputi perlunya pembentukan peraturan yang mengatur tata cara pengelolaan sampah Kota Bima, perlunya pembentukan payung aturan untuk mendorong pengolahan sampah berbasis masyarakat, penyusunan peraturan daerah tentang pengolahan sampah, penyusunan peraturan daerah tentang pengoperasian TPA, dan penegakkan peraturan harus di galakkan.

\section{Pengembangan subsistem peran serta masyarakat}

Kesadaran masyarakat mengenai pengelolaan sampah cukup tinggi dan responden memiliki kemauan untuk bekerjasama dalam pemilahan sampah berdasarkan hasil survei mengenai kesadaran masyarakat. Hal-hal yang diusulkan berkaitan dengan peningkatan peran serta masyarakat, meliputi mengoptimalkan penyuluhan/kampanye, memilah sampah sejak dari sumbernya, berpartisipasi dalam kegiatan gotong-royong, berpartisipasi dalam kegiatan lomba kebersihan, dan internalisasi penanganan sampah ke kurikulum sekolah.

\section{Pengembangan subsistem pembiayaan Rencana biaya operasional pengelolaan}

Berdasarkan hasil perhitungan proyeksi kebutuhan sarana dan prasarana dan rencana pengelolaan sampah di Kota Bima, maka dapat dibuat perkiraan biaya investasi yang diperlukan selama 20 tahun yang akan datang. Adapun biaya investasi pengelolaan sampah di Kota Bima dapat dilihat pada Tabel 7 dan 8.

Berdasarkan perhitungan pada Tabel 7, total investasi per satu kali periode pengadaan dengan umur teknis kendaraan rata-rata selama 7 tahun adalah Rp. 24.437.000.000. Lama proyek yang direncanakan adalah selama 20 tahun dan umur teknis kendaraan selama 7 tahun, sehingga terjadi pengadaan selama umur proyek adalah sebanyak 3 kali pengadaan sarana pengangkutan sampah. Nilai sisa yang diperoleh per periode pengadaan adalah $\mathrm{Rp}$. 17.105.900.000,- sehingga total nilai sisa dari tiga kali pengadaan adalah sebanyak $\mathrm{Rp}$. 51.317.700.000.

Tabel 7. Biaya investasi pekerjaan sipil

\begin{tabular}{|c|c|c|c|c|}
\hline No. & Uraian & $\begin{array}{l}\text { Vol. } \\
\text { (Unit) }\end{array}$ & $\begin{array}{c}\text { Harga Satuan } \\
\text { (Juta Rp.) }\end{array}$ & $\begin{array}{c}\text { Jumlah Harga } \\
\text { (Juta Rp.) }\end{array}$ \\
\hline 1 & Pembuatan TPA sanitary landfill & 1 & 5.300 & 5.300 \\
\hline 2 & Unit pengolahan sampah & 1 & 1.000 & 1.000 \\
\hline 3 & Kantor/rumah jaga & 1 & 60 & 60 \\
\hline 4 & Garase truk & 1 & 40 & 40 \\
\hline 5 & Jalan masuk & 1 & 700 & 700 \\
\hline 6 & Timbangan & 1 & 150 & 150 \\
\hline 7 & Pagar keliling & 1 & 150 & 150 \\
\hline 8 & Kolom pengolahan lindi & 1 & 500 & 500 \\
\hline 9 & Sumur uji & 1 & 30 & 30 \\
\hline 10 & Penghijauan dan taman & 1 & 35 & 35 \\
\hline 11 & Pembuatan lokasi transfer depo & 2 & 200 & 400 \\
\hline & Total & & & 8.365 \\
\hline
\end{tabular}

Sumber: hasil analisa, 2013

Tabel 8. Biaya investasi pengadaan alat

\begin{tabular}{|c|c|c|c|c|c|c|c|}
\hline No. & Uraian & $\begin{array}{c}\text { Umur } \\
\text { Teknis }\end{array}$ & $\begin{array}{l}\text { Vol. } \\
\text { (Unit) }\end{array}$ & $\begin{array}{c}\text { Harga } \\
\text { satuan } \\
\text { (Juta Rp.) }\end{array}$ & $\begin{array}{c}\text { Jumlah } \\
\text { Harga } \\
\text { (Juta Rp.) }\end{array}$ & $\begin{array}{c}\text { Penyusuta } \\
\text { n 10\% per } \\
\text { tahun } \\
\text { (Juta Rp.) }\end{array}$ & $\begin{array}{c}\text { Nilai Sisa } \\
\text { per periode } \\
\text { (Juta Rp.) }\end{array}$ \\
\hline 1 & Dump truck & 7 & 30 & 280 & 8.400 & 840 & 5.880 \\
\hline 2 & Arm roll truck & 7 & 31 & 267 & 8.277 & 827,7 & $5.793,9$ \\
\hline 3 & Motor roda tiga & 7 & 166 & 35 & 5.810 & 581 & 4.067 \\
\hline 4 & Container & 7 & 90 & 18 & 1.620 & 162 & 1.134 \\
\hline 5 & Gerobak & 7 & 110 & 3 & 330 & 33 & 231 \\
\hline \multicolumn{5}{|c|}{ Jumlah } & 24.437 & $2.443,7$ & $17.105,9$ \\
\hline
\end{tabular}

Sumber: hasil analisa, 2013 


\section{Pendapatan Pengelolaan Sampah}

Penjualan pupuk kompos di asumsikan dengan harga Rp. 10.000 per $20 \mathrm{~kg}$. Sedangkan sampah anorganik diasumsikan berdasarkan harga yang berlaku di wilayah Surabaya, karena kondisi pada saat ini lokasi penjualan sampah anorganik yang berasal di wilayah Kota Bima dijual ke pabrik-pabrik yang berada di Surabaya.

Berdasarkan hasil perhitungan, diketahui bahwa keuntungan baru dapat diperoleh pada tahun ke 13 yaitu tahun 2024 dengan jumlah keuntungan sebesar Rp. 743.824.600,- dan mengalami peningkatan tiap tahunnya. Pada tahun terakhir masa rencana yaitu tahun 2032 mendapatkan keuntungan pengolahan sampah sebesar Rp. 27.632.079.000 dan ditambah dengan biaya dari nilai sisa penyusutan alat pengangkutan sampah, yaitu sejumlah Rp. 51.317.700.000, sehinggga total keuntungan bersih di akhir tahun proyek adalah $\mathrm{Rp}$. 78.949.779.000.

\section{KESIMPULAN}

Sistem pengelolaan sampah di Kota Bima dengan metode konvensional berdampak buruk terhadap lingkungan dan kesehatan masyarakat. Pengelolaan dengan kegiatan pengumpulan, pengangkutan dan pembuangan akhir dengan TPA open dumping sudah melanggar dari amanah UU No. 18 tahun 2008, sehingga dipandang perlu melakukan perencanaan sistem pengelolaan yang baru. Sistem pengelolaan sampah non konvensioanal dapat sebagai salah satu metode yang dapat diterapkan, karena menambahkan kegiatan penanganan dan pengolahan sampah pada setiap tahapan kegiatannya. Hal ini dapat terlihat dengan berkurangnya jumlah sampah yang dibuang ke TPA dan dapat memberikan keuntungan finansial dalam pengelolaannya.

\section{DAFTAR PUSTAKA}

Anonim, 1994, Metode Pengambilan dan Pengukuran Contoh Timbulan dan Komposisi Sampah Perkotaan. Standar SK SNI 19-3964-1994, Badan Standarisasi Nasional. Jakarta.

Anonim, 1995, Spesifikasi Timbulan Sampah Untuk Kota Kecil dan Sedang di
Indonesia. Standar SK SNI 19-3983-1995, Badan Standarisasi Nasional. Jakarta.

Anonim, 1998, Petunjuk Teknis Nomor CT/S/Re-TC/004/98 tentang Tata Cara Perencanaan TPA Sampah. Departemen Pekerjaan Umum Direktorat Jenderal Cipta Karya.

Anonim, 2002, Tata Cara Teknik Pengelolaan Sampah Perkotaan. Standar SK SNI 192454-2002, Badan Standarisasi Nasional. Jakarta.

Anonim, 2003, Pedoman Pengelolaan Sampah Perkotaan bagi Pelaksana. Departemen Pemukiman dan Prasarana Wilayah, Direktorat Jendral Tata Perkotaan dan Tata Pedesaan. Jakarta.

Anonim, 2008, Tata Cara Pengelolaan Sampah di Pemukiman. Standar SK SNI 3242-2008, Badan Standarisasi Nasional. Jakarta.

Anonim, 2008. Undang-undang Republik Indonesia Nomor 18. 2008 Tentang Pengelolaan Sampah. Dewan Perwakilan Rakyat Republik Indonesia Dan Presiden Republik Indonesia, Jakarta.

Anonim, 2012. Kota Bima dalam Angka. Balai Pusat Statistik Kota Bima, Kota Bima.

Anonim, 2013. Laporan Pengelolaan Sampah Kota Bima. Dinas Kebersihan Pertamanan dan Pemakaman Kota Bima, Kota Bima.

Asteria, D., dan Heru, H. 2016. Bank Sampah Sebagai Alternatif Strategi Pengelolaan Sampah Berbasis Masyarakat di Tasikmalaya. J. Manusia dan Lingkungan 23(1):136-141.

Cecep, S.D. 2012. Teknologi Pengolahan Daur Ulang Sampah. Gosyen Publishing. Yogyakarta.

Chalik, A. A., Bibiana W. L., Akhmad F., Etty R. 2011. Formulasi Kebijakan Sistem Pengolahan Sampah Perkotaan Berkelanjutan "Stud Kasus DKI Jakarta". Jurnal Permukiman 6 (1): 18-30.

Darmawan, A., 2014. Perilaku Masyarakat dalam Mengelola Sampah di Kota Bima Nusa Tenggara Barat. Jurnal Pembangunan Wilayah dan Kota 10(2):175-186.

Enri, D., dan Tri, P. 2010. Diktat Kuliah TL3150 Pengelolaan Sampah. Program Studi Teknik Lingkungan. FTSL, Institut Teknologi Bandung. Bandung. 
Irene, L. 1999. Environmental Engineers Handbook. Princeton, New Jersey.

Klundert, A.van de, dan Anschütz, J., 2001. Integrated Sustainable Waste Management. Series editor: Anne Scheinberg. Netherlands.

Kodoatie, R.J., 2005. Pengantar Manajemen Infranstruktur. Pustaka Pelajar. Yogyakarta.

Mulasari, S.A., Adi, H.H., dan Noeng, M., 2014. Kebijakan Pemerintah dalam Pengelolaan Sampah Domestik. Jurnal Kesehatan Masyarakat Nasional, 8(8):404-410.

Puspitawati, Y., dan Mardwi, R., 2012. Kajian Pengelolaan Sampah Berbasis Masyarakat dengan Konsep 3R (Residu, Reuse, Recycle) di Kelurahan Larangan Kota Cirebon. Jurnal Pembangunan Wilayah dan Kota, 8(4):349-359.

Raharjo, S., Taufiq, I., dan Tiara, W., 2016. Pengembangan Pengelolaan Sampah
Perkotaan dengan Pola Pemanfaatan Sampah Berbasis Masyarakat di Kabupaten Tanah Datar. Jurnal Teknik Lingkungan, 13(2):77-88.

Rizal, M., 2011. Analisis Pengelolaan Sampah Perkotaan (Studi Kasus pada Kelurahan Boya Kecamatan Banawa Kabupaten Donggala. Jurnal Smartek 9(2):155-172.

Sahil, J., Mimien, H.I.A.M, Fachtur, R., dan Istamar, S., 2016. Sistem Pengelolaan dan Upaya Penanggulangan Sampah di Kelurahan Dufa-Dufa Kota Ternate. Jurnal Bioedukasi 4(2):478-487.

Tchobanoglous, G., dan Kreith F., 2002. Handbook of Solid Waste Management. Second Edition. McGRAW-HILL. New York.

Wardhana, I.W., 2007. Rencana Pengembangan Teknik Pengelolaan Sampah Kota Juwana. Jurnal Presipitasi, 3(2):102-110. 